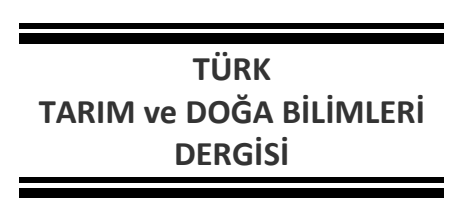

\section{Determination of Greenhouse Gas}

TURKISH

JOURNAL Of AGRICULTURAL and NATURAL SCIENCES

www.dergipark.gov.tr/turkjans

Research Article

Plants in Turkey

\author{
Ömer EREN ${ }^{1 *}$, Osman GÖKDOĞAN² ${ }^{2}$ Mehmet Fırat BARAN ${ }^{3}$ \\ ${ }^{* 1}$ Department of Biosystem Engineering, Faculty of Agricultural, University of Hatay Mustafa Kemal, 31060 \\ Hatay, Turkey \\ ${ }^{2}$ Department of Biosystem Engineering, Faculty of Engineering-Architecture, University of Nevşehir Hacı Bektaş \\ Veli, 50300 Nevşehir, Turkey \\ ${ }^{3}$ Department of Energy Systems Engineering, Faculty of Technology, University of Adıyaman, 02040 Adıyaman,
} Turkey

*Corresponding author: dromereren@gmail.com

Received: 16.09 .2018

Received in Revised: 15.01.2019

Accepted: 16.01 .2019

\begin{abstract}
The release of greenhouse gas emissions is a source of great concern for Turkey. However, agriculture is among the key actors in terms of environmental impact in Turkey, as agriculture not only consumes energy but it also produces it and it can have both positive and negative effects on the environment. This study was conducted in order to determine GHG emissions for four different medical, aromatic and pleasure plants production (guar, lavender, sesame and tobacco) in the different provinces of Turkey. For this purpose, the first data was collected from references. The results indicated that total GHG emissions for four different aromatic plants production (guar, lavender, sesame and tobacco) production were computed as $1488.50 \mathrm{kgCO}_{2 \text {-eqha }}{ }^{-1}$, $494.81 \mathrm{kgCO}_{2 \text {-eq }} \mathrm{ha}^{-1}, 907.13 \mathrm{kgCO}_{\text {2-eq }} \mathrm{ha}^{-1}, 6604.58 \mathrm{kgCO}_{\text {2-eqha }}{ }^{-1}$ respectively. The $\mathrm{GHG}$ ratios were computed as $0.65 \mathrm{kgCO}_{2 \text {-eq }} \mathrm{kg}^{-1}, 0.10 \mathrm{kgCO}_{2 \text {-eq }} \mathrm{kg}^{-1}, 1.88 \mathrm{kgCO}_{\text {2-eq }} \mathrm{kg}^{-1}, 6.29 \mathrm{kgCO}_{\text {2-eq }} \mathrm{kg}^{-1}$ respectively.
\end{abstract}

Key words: GHG emissions, GHG ratio, aromatic plants, Turkey.

\title{
Türkiye'de Farklı Aromatik Bitkilerin Üretilmesinde Sera Gazı Emisyonlarının (GHG) Belirlenmesi
}

\begin{abstract}
Özet
Sera gazı emisyonlarının salınması, Türkiye için büyük bir endişe kaynağıdır. Ancak, sadece enerji tüketmekle kalmayıp aynı zamanda çevre üzerinde hem olumlu hem de olumsuz etkileri olabileceği için Türkiye'de tarım çevresel etkilerin en önemli aktörleri arasında yer almaktadır. Bu çalışma, Türkiye'nin farklı illerinde dört farklı tıbbi, aromatik ve keyif bitkisinin (guar, lavanta, susam ve tütün) üretimi sırasında oluşan sera gazı emisyonlarının belirlenmesi amacıyla yapılmıştır. Bu amaçla ilk veriler referanslardan toplanmıştır. Sonuçta, dört farklı aromatik bitkinin (guar, lavanta, susam ve tütün) üretimi sırasında oluşan toplam sera gazı emisyonları sırasıyla $1488.50 \mathrm{kgCO}_{2 \text {-eşha }}{ }^{-1}, 494.81 \mathrm{kgCO}_{2 \text {-eşha }} \mathrm{h}^{-1}, 907.13 \mathrm{kgCO}_{2 \text {-eşha }}{ }^{-1}$ ve $6604.58 \mathrm{kgCO}_{2 \text {-eşha }} \mathrm{h}^{-1}$

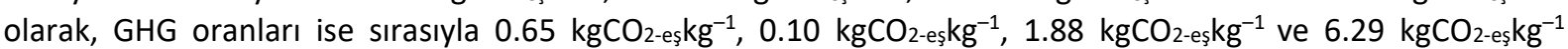
olarak hesaplanmıştır.
\end{abstract}

Anahtar kelimeler: GHG emisyonları, GHG oranı, aromatik bitkiler, Türkiye.

\section{Introduction}

Emission of a greenhouse gas (GHG) is something that both absorbs and emits radiation in atmosphere within a thermal infrared range
(Nabavi-Pelesaraei et al., 2016). The GHG emissions are divided into two categories: namely anthropogenic and natural sources. Agricultural activities contribute directly to anthropogenic GHG 
emissions that their sources vary greatly, such as machinery, diesel fuel, fertilizers, biocides and electricity to name a few.

The most important direct GHG emissions are caused by chemical fertilizer use, and out of all GHG emissions, they represent around $20 \%$ and $30 \%$, including smaller and larger farms (Lal, 2004).

A great number of practices have been examined with the purpose of decreasing the annual GHG release. These practises in question include crop nutrition, precision farming practices, tillage improvement, land grazing, livestock and manure management. Having a limited amount of energy resources as well as the great level of dependence on fossil fuels by agriculture have forced researchers to seek means of energy use efficiency in different crops and in different soils. Increasing the efficiency when using energy inputs will contribute for lower GHG emissions and environmental footprints, and consequently, food production systems will become more sustainable (Houshyar et al., 2015).
In 2017 (TUIK, 2018), agricultural activities were responsible for emissions of $56.56 \mathrm{Mt} \mathrm{CO}_{2 \text {-eq }}$ or $11.40 \%$ of total greenhouse gas emissions in Turkey. Agricultural activities come third after the energy and industrial sectors. $\mathrm{CH}_{4}, \mathrm{~N}_{2} \mathrm{O}$, and $\mathrm{CO}_{2}$ were the primary greenhouse gases emitted by agricultural activities. $77.6 \%$ of $\mathrm{N}_{2} \mathrm{O}$ emissions, $55.5 \%$ of $\mathrm{CH}_{4}$ emissions and $0.3 \%$ of $\mathrm{CO}_{2}$ emissions were caused by agricultural activities.

Several studies on determination of GHG emission have been concentrated generally on worldwide production of crops such as guar (Gresta et al., 2014), sesame (Sadiq et al., 2016), tobacco (Pardis and Devakumar, 2014; Tongwane et al., 2016), other fruits and vegetables (Garnett, 2006; Vetter et al., 2017) etc.

The aims of this study were to computed total GHG emissions and the GHG ratios of four different aromatic plants production (guar, lavender, sesame and tobacco) in the different locations (Table 1) of Turkey.

Table 1. References benefited for agricultural inputs and outputs of four different aromatic plants production

\begin{tabular}{ccc}
\hline Plants & Location & References \\
\hline Guar & Bingöl & Gökdoğan et al., 2017 \\
Lavender & Isparta & Gökdoğan, 2016 \\
Sesame & Şanlıurfa & Baran and Gökdoğan, 2017 \\
Tobacco & Adıyaman & Baran and Gökdoğan, 2015 \\
\hline
\end{tabular}

\section{Material and Methods}

This study is made up of agricultural inputs and outputs of references in Table 1.

The GHG emissions (kg $\mathrm{CO}_{2-\text { eq }} \mathrm{ha}^{-1}$ ) associated with the inputs to growing 1 ha of aromatic plants were computed as following (adapted Hughes et al., 2011).

$$
G H G_{h a}=\sum_{i=1}^{n} R(i) x E F(i)
$$

$\sum$ where $R(i)$ is the application rate of input $i$ (unitinput $\mathrm{ha}^{-1}$ ) and $\mathrm{EF}(i)$ is the GHG emission coefficient of input $i\left(\mathrm{~kg} \mathrm{CO}_{2 \text {-eq }}\right.$ unitinput $\left.^{-1}\right)$. Table 2 lists GHG emission coefficients of agricultural inputs.

Moreover, an index is defined to evaluate the amount of emitted $\mathrm{kg} \mathrm{CO}_{2}$-eq per $\mathrm{kg}$ yield as following (adapted Khoshnevisan et al., 2014 and Housyar et al., 2015).

$$
I_{G H G}=\frac{G H G_{h a}}{Y}
$$

Where $I_{G H G}$ is GHG ratio and $Y$ is the yield as $\mathrm{kg}$ per ha.

Table 2. Greenhouse gas (GHG) emission coefficients of agricultural inputs

\begin{tabular}{cccc}
\hline Inputs & Unit & GHG coefficient $\left(\mathbf{k g ~ C O}_{\text {2-eq }}\right.$ Unit $\left.^{-\mathbf{1}}\right)$ & References \\
\hline Human labour & $\mathrm{h}$ & 0.700 & Nguyen and Hermansen, 2012 \\
Machinery & $\mathrm{MJ}$ & 0.071 & Pisghar-Komleh et al., 2012 \\
Nitrogen $(\mathrm{N})$ & $\mathrm{kg}$ & 4.570 & BioGrace-II, 2015 \\
Phosphate $\left(\mathrm{P}_{2} \mathrm{O}_{5}\right)$ & $\mathrm{kg}$ & 1.180 & BioGrace-II, 2015 \\
Potassium $\left(\mathrm{K}_{2} \mathrm{O}\right)$ & $\mathrm{kg}$ & 0.640 & BioGrace-II, 2015 \\
Pesticides & $\mathrm{kg}$ & 13.900 & BioGrace-II, 2015 \\
Diesel fuel & $\mathrm{L}$ & 2.760 & Clark et al., 2016 \\
Water of irrigation & $\mathrm{m}^{3}$ & 0.170 & Lal, 2004 \\
Sulphur & $\mathrm{kg}$ & 0.370 & Maraseni et al., 2010 \\
Seed & $\mathrm{kg}$ & 7.630 & Clark et al., 2016 \\
\hline
\end{tabular}




\section{Results and Discussion \\ GHG emissions \\ Guar production}

The results of GHG emission of guar production for Bingöl Province in Turkey are shown in Table 3. The total GHG emissions were computed as $1488.50 \mathrm{~kg} \mathrm{CO}_{2 \text {-eq }} \mathrm{ha}^{-1}$. In similar a study, Gresta et al. (2014) computed the total GHG emission of guar production in southern Italy was about $2751.40 \mathrm{~kg} \mathrm{CO}_{2 \text {-eq }} \mathrm{ha}^{-1}$ and $2905.50 \mathrm{~kg} \mathrm{CO}_{2 \text {-eq }}$ $\mathrm{ha}^{-1}$.
The distribution of different inputs in total GHG emissions is illustrated in Figure 1. The results showed that the share of human labour in total GHG emissions was the highest (32.25\%), machinery (17.66\%) and diesel fuel (15.89\%) held the second and third ranks. So, better agricultural management in terms of human labour can lead to guar production with lower GHG emissions in location.

Table 3. Greenhouse gas emissions of inputs in guar production

\begin{tabular}{cccc}
\hline Inputs & Unit & Input used per area $\left(\right.$ Unit ha $\left.\mathbf{~}^{-1}\right)$ & GHG Emissions $\left(\mathbf{k g ~ C O}_{\text {2-eq }} \mathbf{h a}^{-\mathbf{1}}\right)$ \\
\hline Human labour & $\mathrm{h}$ & 685.71 & 480.00 \\
Machinery & $\mathrm{MJ}$ & 3702.67 & 262.89 \\
Nitrogen $(\mathrm{N})$ & $\mathrm{kg}$ & 36.91 & 168.68 \\
Phospate $\left(\mathrm{P}_{2} \mathrm{O}_{5}\right)$ & $\mathrm{kg}$ & 39.61 & 46.74 \\
Potassium $\left(\mathrm{K}_{2} \mathrm{O}\right)$ & $\mathrm{kg}$ & 17.00 & 10.88 \\
Diesel fuel & $\mathrm{L}$ & 85.71 & 236.56 \\
Water of irrigation & $\mathrm{m}^{3}$ & 316.80 & 53.86 \\
Seed & $\mathrm{kg}$ & 30.00 & 228.90 \\
& & Total GHG Emission & 1488.50 \\
\hline
\end{tabular}

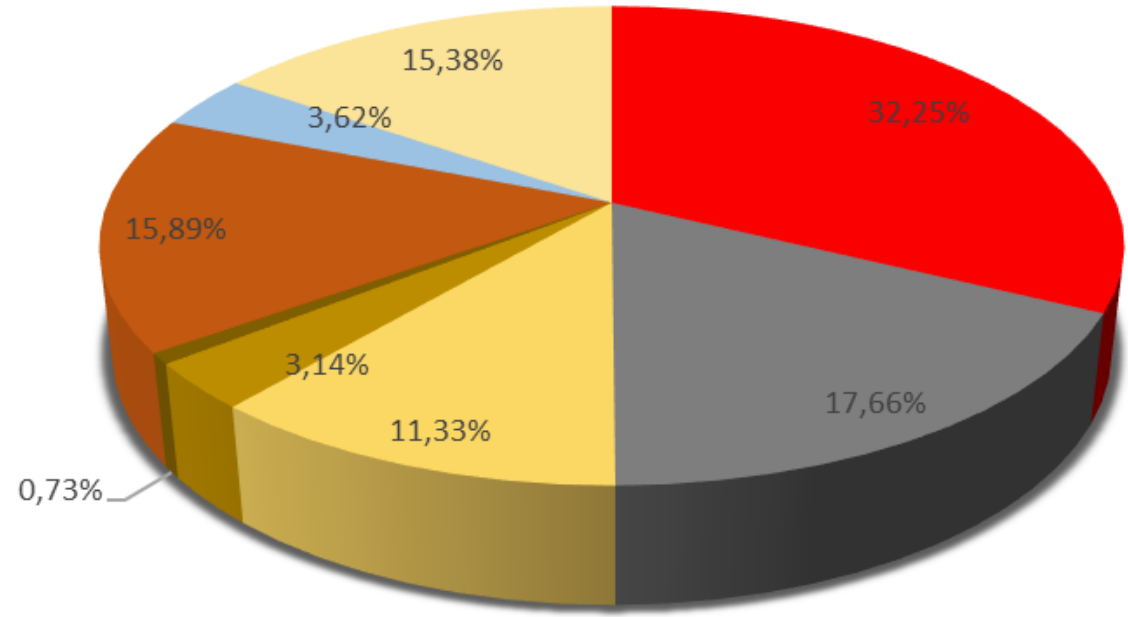

- Human labour

- Machinery

Nitrogen $(\mathrm{N})$

- Phospate (P2O5)

- Potassium (K2O)

Diesel Fuel

Water of irrigation

Seed

Figure 1. The distribution of different inputs in total GHG emission of guar production

\section{Lavender production}

The results of GHG emission of lavender production for Isparta Province in Turkey are shown in Table 4. The total GHG emissions were computed as $494.81 \mathrm{~kg} \mathrm{CO}_{2 \text {-eq }} \mathrm{ha}^{-1}$.

The distribution of different inputs in total GHG emissions is illustrated in Figure 2. The results showed that the share of nitrogen fertilizer in total GHG emissions was the highest (44.24\%), diesel fuel $(20.92 \%)$ and human labour $(13.68 \%)$ held the second and third ranks. So, better agricultural management in terms of nitrogen fertilizer can lead to lavender production with lower GHG emissions in location.

\section{Sesame production}

The results of GHG emission of melon production for Şanlıurfa Province in Turkey are shown in Table 5. The total GHG emissions were computed as $907.13 \mathrm{~kg} \mathrm{CO}_{2 \text {-eq }} \mathrm{ha}^{-1}$. In similar a study, Sadiq et al. (2016) computed the total GHG emission of sesame production in Jigawa State of Nigeria was about $40.57 \mathrm{~kg} \mathrm{CO}_{2 \text {-eq }} \mathrm{ha}^{-1}$ (efficient farmers) and $56.50 \mathrm{~kg} \mathrm{CO}$-eq ha ${ }^{-1}$ (inefficient farmers).

The distribution of different inputs in total GHG emissions is illustrated in Figure 3 . The results showed that the share of nitrogen fertilizer in total 
GHG emissions was the highest (33.25\%), human labour (19.21\%) and phosphate fertilizer (13.66\%) held the second and third ranks. So, better agricultural management in terms of nitrogen fertilizer can lead to sesame production with lower GHG emissions in location.

Table 4. Greenhouse gas emissions of inputs in lavender production

\begin{tabular}{|c|c|c|c|}
\hline Inputs & Unit & Input used per area (Unit ha-1) & GHG Emissions (kg CO${ }_{2 \text { eq }} \mathrm{ha}^{-1}$ ) \\
\hline Human labour & $\mathrm{h}$ & 96.73 & 67.71 \\
\hline Machinery & MJ & 615.60 & 43.71 \\
\hline Nitrogen $(N)$ & $\mathrm{kg}$ & 47.90 & 218.90 \\
\hline Phospate $\left(\mathrm{P}_{2} \mathrm{O}_{5}\right)$ & $\mathrm{kg}$ & 28.50 & 33.63 \\
\hline Potassium $\left(\mathrm{K}_{2} \mathrm{O}\right)$ & $\mathrm{kg}$ & 17.00 & 10.88 \\
\hline Sulphur & $\mathrm{kg}$ & 15.60 & 5.77 \\
\hline Pesticides & $\mathrm{kg}$ & 0.77 & 10.70 \\
\hline \multirow[t]{2}{*}{ Diesel fuel } & $\mathrm{L}$ & 37.50 & 103.50 \\
\hline & & Total GHG Emission & 494.81 \\
\hline
\end{tabular}

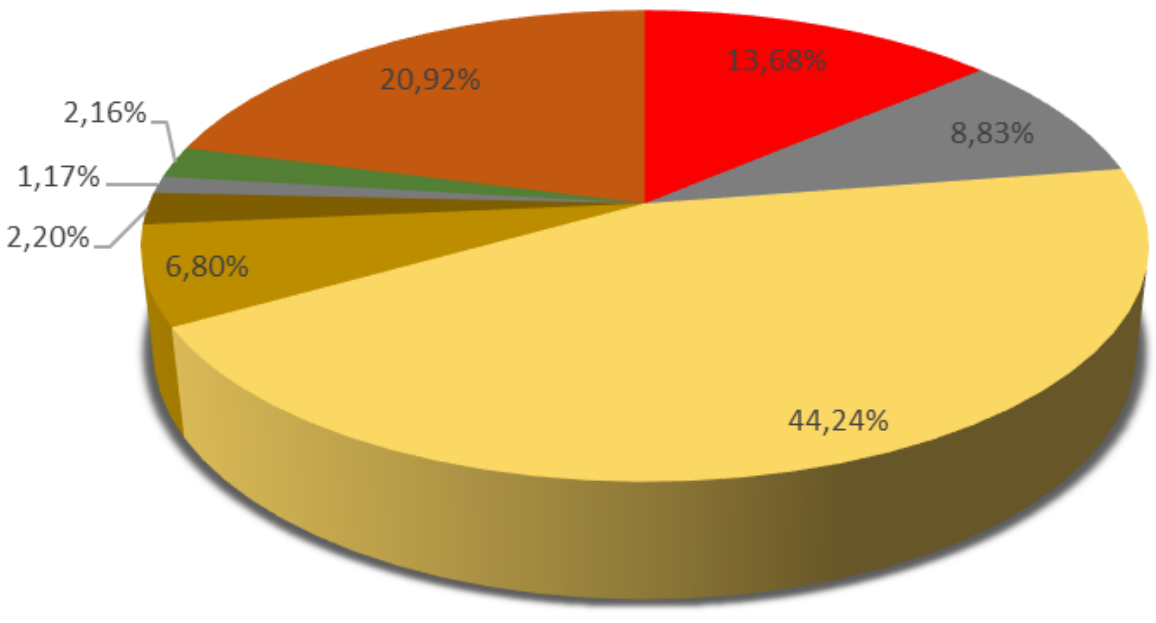

- Human labour

- Machinery

Nitrogen $(\mathrm{N})$

- Phospate (P2O5)

- Potassium (K2O)

- Sulphur

- Pesticides

n Diesel Fuel

Figure 2. The distribution of different inputs in total GHG emission of lavender production

Table 5. Greenhouse gas emissions of inputs in sesame production

\begin{tabular}{cccc}
\hline Inputs & Unit & Input used per area (Unit ha-1 & GHG Emissions $\left(\mathbf{k g ~ C O}_{\text {2-eq }}\right.$ ha $^{-\mathbf{1}}$ ) \\
\hline Human labour & $\mathrm{h}$ & 248.90 & 174.23 \\
Machinery & $\mathrm{MJ}$ & 1289.52 & 91.56 \\
Nitrogen $(\mathrm{N})$ & $\mathrm{kg}$ & 66.00 & 301.62 \\
Phospate $\left(\mathrm{P}_{2} \mathrm{O}_{5}\right)$ & $\mathrm{kg}$ & 105.00 & 123.90 \\
Potassium $\left(\mathrm{K}_{2} \mathrm{O}\right)$ & $\mathrm{kg}$ & 50.00 & 32.00 \\
Sulphur & $\mathrm{kg}$ & 10.00 & 3.70 \\
Pesticides & $\mathrm{kg}$ & 0.50 & 6.95 \\
Diesel fuel & $\mathrm{L}$ & 37.00 & 102.12 \\
Water of irrigation & $\mathrm{m}^{3}$ & 216.00 & 36.72 \\
Seed & $\mathrm{kg}$ & 4.50 & 34.34 \\
& & Total GHG Emission & 907.13 \\
\hline
\end{tabular}

\section{Tobacco production}

The results of GHG emission of tobacco production for Adıyaman Province in Turkey are shown in Table 6. The total GHG emissions were computed as $6604.58 \mathrm{~kg} \mathrm{CO}_{2 \text {-eq }} \mathrm{ha}^{-1}$. In similar studies, Pardis and Devakumar (2014) computed the total GHG emission of tobacco production in
Southern India was about $200 \mathrm{~kg} \mathrm{CO}$-eq $\mathrm{ha}^{-1}$, Tongwane et al. (2016) computed the total GHG emission of tobacco production in Southern Africa was about $360 \mathrm{~kg} \mathrm{CO}_{2 \text {-eq }} \mathrm{ha}^{-1}$.

The distribution of different inputs in total GHG emissions is illustrated in Figure 4. The results showed that the share of human labour in total 
GHG emissions was the highest (67.62\%), water of irrigation (11.55\%) and nitrogen fertilizer (10.17\%) held the second and third ranks. So, better agricultural management in terms of human labour can lead to tobacco production with lower GHG emissions

in location.
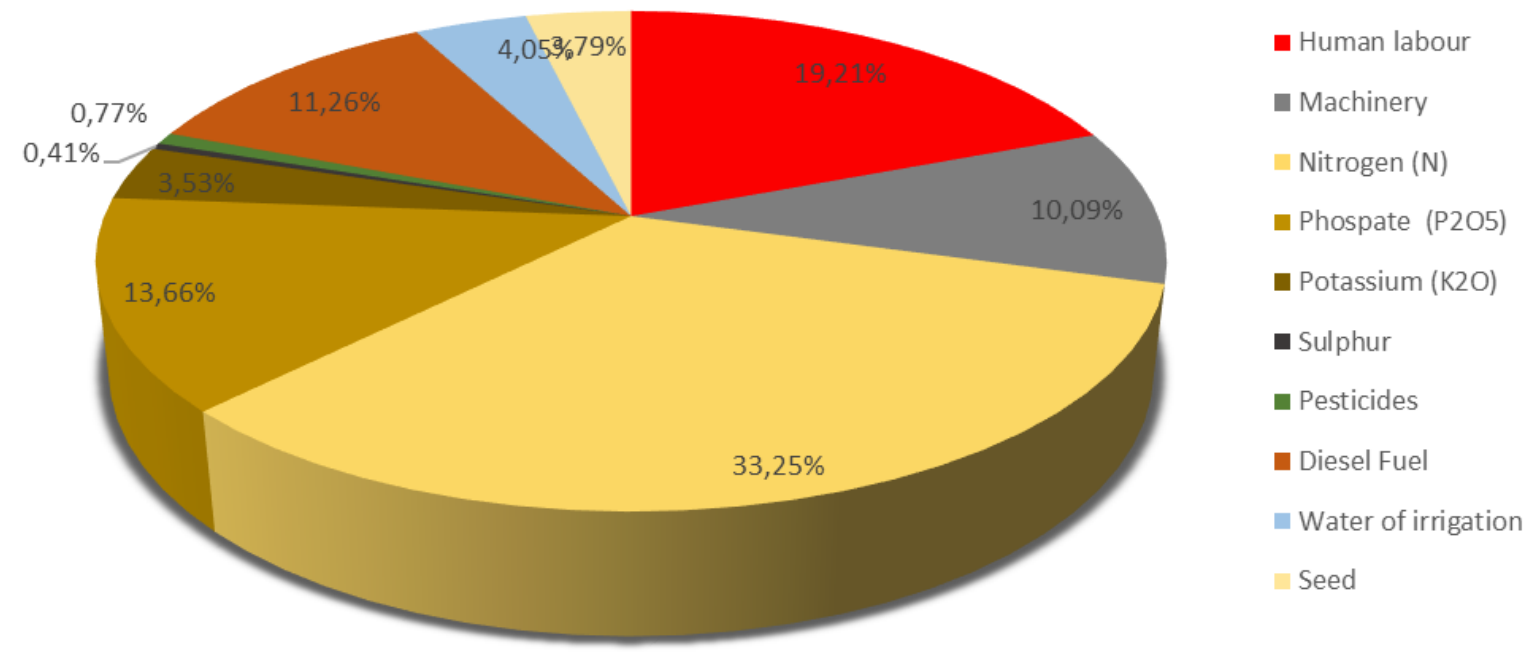

Figure 3. The distribution of different inputs in total GHG emission of sesame production

Table 6. Greenhouse gas emissions of inputs in tobacco production

\begin{tabular}{cccc}
\hline Inputs & Unit & Input used per area (Unit ha $\mathbf{~}^{-\mathbf{1}}$ ) & GHG Emissions (kg CO $_{\text {2-eq }}$ ha $^{\mathbf{- 1}}$ ) \\
\hline Human labour & $\mathrm{h}$ & 6379.60 & 4465.72 \\
Machinery & $\mathrm{MJ}$ & 3633.34 & 257.97 \\
Nitrogen $(\mathrm{N})$ & $\mathrm{kg}$ & 147.00 & 671.79 \\
Phospate $\left(\mathrm{P}_{2} \mathrm{O}_{5}\right)$ & $\mathrm{kg}$ & 73.50 & 86.73 \\
Potassium $\left(\mathrm{K}_{2} \mathrm{O}\right)$ & $\mathrm{kg}$ & 189.00 & 120.96 \\
Pesticides & $\mathrm{kg}$ & 6.72 & 93.41 \\
Diesel fuel & $\mathrm{L}$ & 52.50 & 144.90 \\
Water of irrigation & $\mathrm{m}^{3}$ & 4488.75 & 763.09 \\
Seed & $\mathrm{kg}$ & 0.002 & 0.02 \\
& & Total GHG Emission & 6604.58 \\
\hline
\end{tabular}
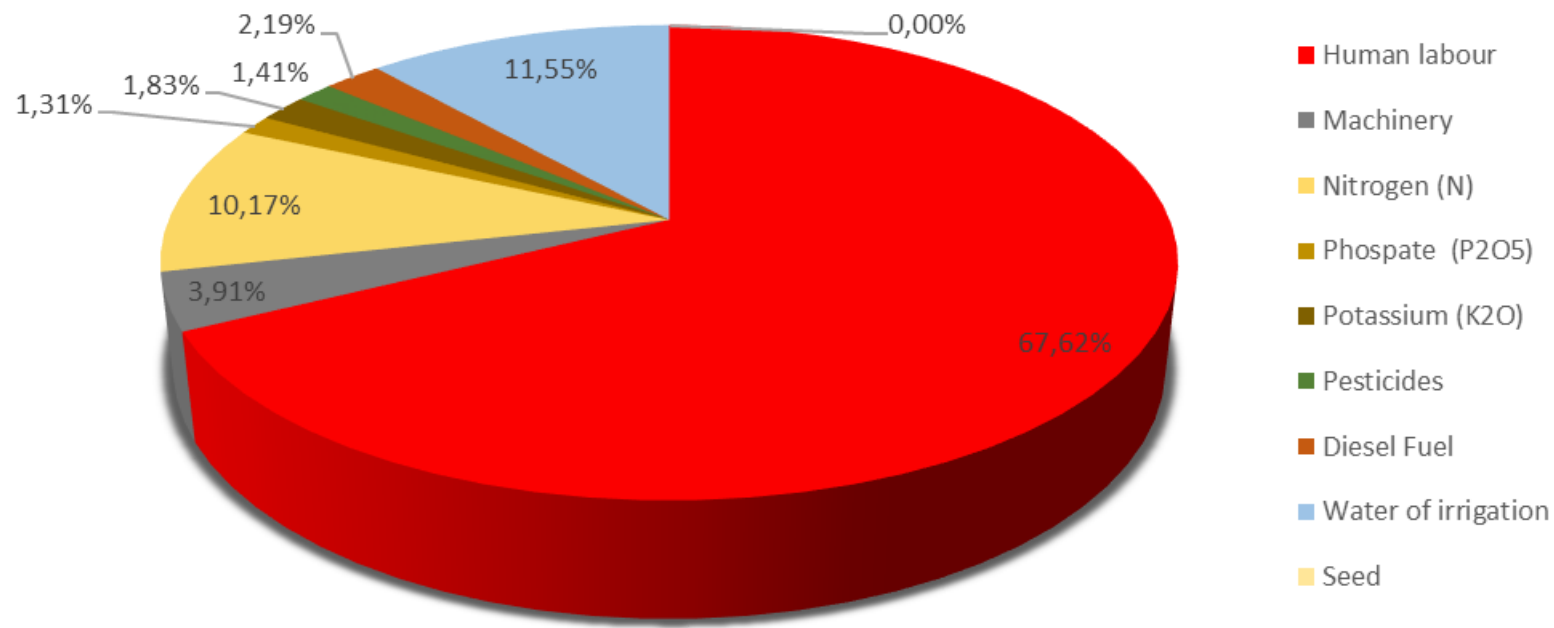

Figure 4. The distribution of different inputs in total GHG emission of tobacco production

\section{Comparison and GHG ratios}

The results of comparison of different aromatic plants productions in Turkey are shown Table 7 and Figure 5. The total GHG emissions were computed between $494.81-6604.58 \mathrm{~kg} \mathrm{CO}_{2}$ eq $\mathrm{ha}^{-1}$. The lowest value was determined for lavender production and the highest value determined for tobacco production. 
The GHG ratios were computed between $0.10-6.29 \mathrm{~kg} \mathrm{CO}_{2 \text {-eq }} \mathrm{kg}^{-1}$. The lowest value was determined for lavender production and the highest value determined for tobacco production.

Table 7. Total GHG emissions, yields and GHG ratios of diffirent aromatic plants productions in Turkey

\begin{tabular}{|c|c|c|c|}
\hline Plants & GHG Emissions (kg CO${ }_{2-e q}$ ha $^{-1}$ ) & Yield (kg ha-1) & GHG Ratio (kg CO${ }_{2 \text {-eq }} \mathrm{kg}^{-1}$ ) \\
\hline Guar & 1488.50 & 2278 & 0.65 \\
\hline Lavender & 494.81 & 4725 & 0.10 \\
\hline Sesame & 907.13 & 482 & 1.88 \\
\hline Tobacco & 6604.58 & 1050 & 6.29 \\
\hline
\end{tabular}

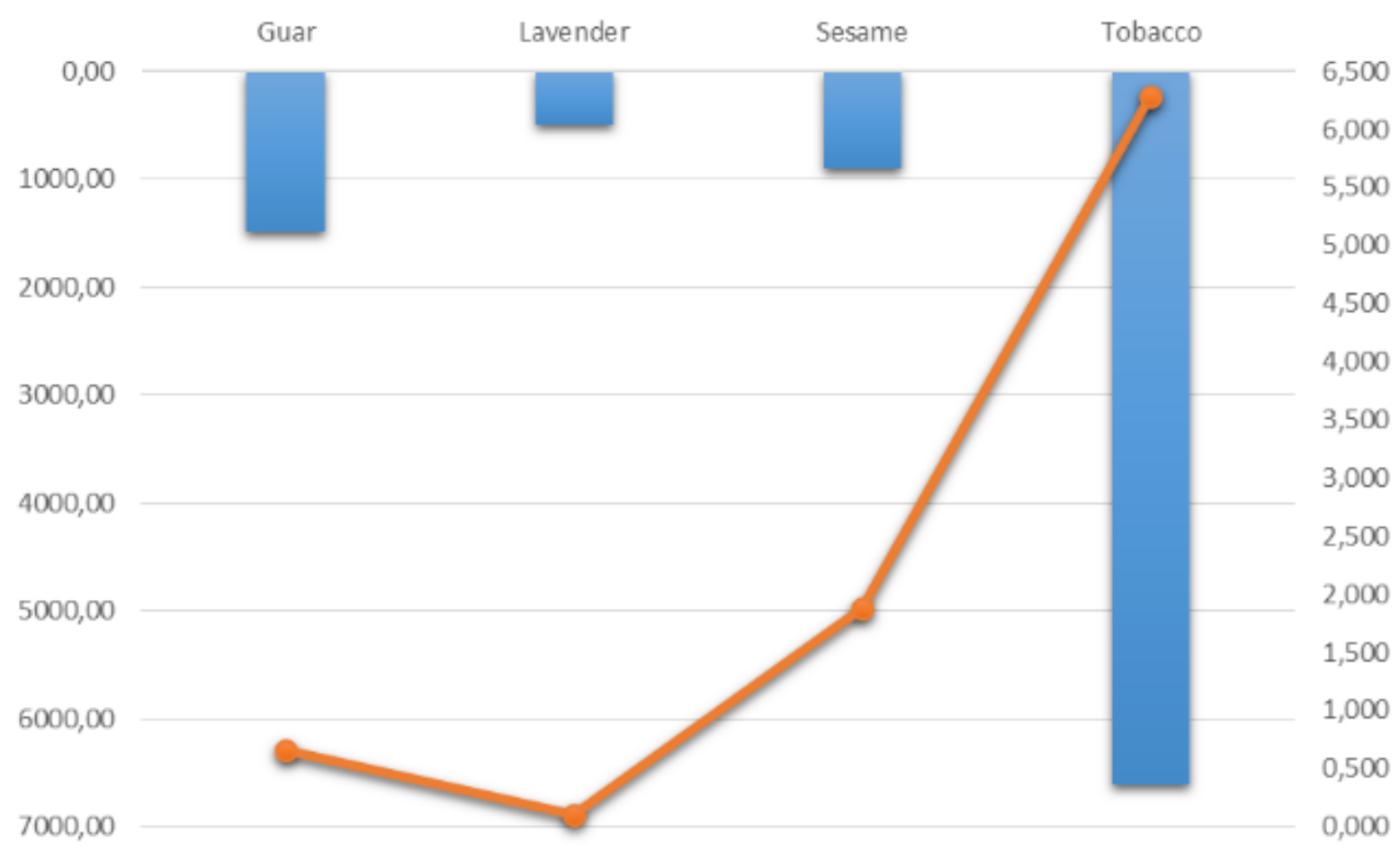

\section{GHG Emissions (kg CO2eq ha-1) —GHG Ratio (kg CO2eq kg-1)}

Figure 5. Total GHG emission and GHG ratio of different aromatic plants production in Turkey

\section{Conclusions}

Based on the results of this study, following conclusions are drawn:

- The results of total GHG emission indicated that the lowest value $\left(494.81 \mathrm{~kg} \mathrm{CO}_{2 \text {-eq }}\right.$ $\mathrm{ha}^{-1}$ ) was determined for lavender production and the highest value $\left(6604.58 \mathrm{~kg} \mathrm{CO}\right.$-eq $\left.\mathrm{ha}^{-1}\right)$ determined for tobacco production.

- The results of the distribution of different inputs in total GHG emissions showed that the share of chemical fertilizer was the highest (53.24\%, 50.44\%, respectively) for lavender and sesame production.

- The results of the distribution of different inputs in total GHG emissions showed that the share of human labour was the highest $(67.62 \%$, $32.25 \%$, respectively) for tobacco and guar production.

- The results of GHG ratio indicated that the lowest value $\left(0.10 \mathrm{~kg} \mathrm{CO}_{2 \text {-eq }} \mathrm{kg}^{-1}\right)$ was determined for lavender production and the highest value (6.29 kg $\mathrm{CO}_{2 \text {-eq }} \mathrm{kg}^{-1}$ ) determined for tobacco production.

- Reducing chemical fertilizer consumption (mainly nitrogen) and human labour are the most important ways in different aromatic plants production in the research regions in Turkey. For this purpose, applying soil analysis to specify the soil fertilizer needs (to decrease high chemical fertilizer causing GHG emissions) and human labour efficiency are recommended.

- GHG emissions should be determined in production of all agricultural products in Turkey.

\section{References}

Baran, M.F., Gökdoğan, O. 2015. Determination of energy input-output of Tobacco production in Turkey. American-Eurasian J. Agric. \& Environ. Sci., 15 (7): 1346-1350. 
Baran, M.F., Gökdoğan, O. 2017. Determination of energy use efficiency of Sesame production. Journal of Tekirdag Agricultural Faculty, 14 (3): 73-79.

BioGrace-II, 2015. Harmonised Calculations of Biofuel Greenhouse Gas Emissions inEurope. BioGrace, Utrecht, The Netherlands. http://www.biograce.net.

Clark, S., Khoshnevisan, B., Sefeedpari, P. 2016. Energy efficiency and greenhouse gas emissions during transition to organic and reduced-input practices: Student farm case study. Ecological Engineering, 88; 186-194.

Garnett, T. 2006. Fruit and Vegetables \& UK Greenhouse Gas Emissions: Exploring the Relationship. Working paper produced as part of the work of the food climate research network.

Gökdoğan, O. 2016. Determination of input-output energy and economic analysis of lavender production in Turkey. Int J Agric \& Biol Eng, 9 (3): 154-161.

Gökdoğan, O., Seydosoğlu, S., Kökten, K., Bengü, A.Ş., Baran, M. F. 2017. Energy input-output analysis of guar (Cyamopsis tetragonoloba) and lupin (Lupinus albus L.) production in Turkey Legume Research, 40(3): 526-531.

Gresta, F., De Luca, A.I., Strano, A., Falcone, G., Santonoceto, C., Anastasi, U., Gulisano, G. 2014. Economic and environmental sustainability analysis of guar (Cyamopsis tetragonoloba L.) farming process in a Mediterranean area: two case studies. Italian Journal of Agronomy, 9(1): 20-24.

Houshyar, E., Dalgaard, T., Tarazgar, M.H., Jorgensen, U. 2015. Energy input for tomato production what economy says, and what is good for the environment. Journal of Cleaner Production, 89: 99-109.

Hughes, D.J., West, J.S., Atkins, S.D., Gladders, P., Jeger, M.J., Fitt, B.D. 2011. Effects of disease control by fungicides on greenhouse gas emissions by U.K. arable crop production. Pest Manag Sci, 67: 1082-1092.

Khoshnevisan, B., Shariati, H. M., Rafiee, S., Mousazadeh, H. 2014. Comparison of energy consumption and GHG emissions of open field and greenhouse strawberry production. Renewable and Sustainable Energy Reviews, 29: 316-324.

Lal, R. 2004. Carbon emission from farm operations. Environment International, 30: 981-990.

Maraseni, T.N., Cockfield, G., Maroulis, J., Chen, G. 2010. An assessment of greenhouse gas emissions from the Australian vegetables industry. Journal of Environmental Science and Health, Part B, 45(6): 578-588.

Nabavi-Pelesaraei, A., Abdi, R., Rafiee, S. 2016. Neural network modeling of energy use and greenhouse gas emissions of watermelon production systems. Journal of the Saudi Society of Agricultural Sciences, 15 (1): 3847.

Nguyen, T.L.T., Hermansen, J.E. 2012. System expansion for handling co-products in LCA of sugar cane bio-energy systems: GHG consequences of using molasses for ethanol production. Applied Energy, 89: 254-261.

Pardis, Devakumar, A.S. 2014. Green house gas emission of major agriculture crops of Southern India. 2nd International Conference on Sustainable Environment and Agriculture, IPCBEE, 76: 94-98.

Pishgar-Komleh, S.H., Ghahderijani, M., Sefeedpari,P. 2012. Energy consumption and $\mathrm{CO}_{2}$ emissions analysis of potato production based on different farm size levels in Iran. Journal of Cleaner Production, 33: 183-191.

Sadiq M.S., Singh I.P., Umar S.M., Grema I.J., Usman B.I., Isah M.A. 2016. Global warming and tragedy of the commons: comparative evidence of greenhouse gas emission $\left(\mathrm{CO}_{2}\right)$ between efficient and inefficient sesame producers in Jigawa State of Nigeria. International Journal of Tropical Agriculture; 34(1): 135-147.

Tongwane, M., Mdlambuzi, T., Moeletsi, M., Tsubo, M., Mliswa, V., Grootboom, L. 2016. Greenhouse gas emissions from different crop production and management practices in South Africa. Environmental Development, 19: 23-35.

TUIK, 2018. GHG Emission Statistics. Turkish Statistical Institute Agency Newsletter. http://www.tuik.gov.tr/PreHaberBultenleri. do?id=27675 (Date of access: 18.08.2018).

Vetter, S.H., Sapkota, T.B. Hillier, J., Stirling, C.M., Macdiarmid, J.I., Aleksandrowicz, L., Green, R., Joy, E.J.M., Dangour, A.D., Smith, P. 2017. Greenhouse gas emissions from agricultural food production to supply Indian diets: Implications for climate change mitigation. Agriculture, Ecosystems \& Environment, 237: 234-241. 